\title{
Leukemia Limfoblastik Akut pada Anak Usia di Bawah Satu Tahun
}

\author{
Sri Mulatsih, Silvia Meiliana \\ Bagian Ilmu Kesehatan Anak, Fakultas Kedokteran UGM /RSUP Dr. Sardjito, Yogyakarta
}

\begin{abstract}
Latar belakang. Angka kejadian leukemia limfoblastik akut (LLA) pada anak usia di bawah satu tahun sekitar 2\%-5\% dari seluruh pasien LLA dengan event-free survival (EFS) untuk 3 sampai 6 tahun hanya 22\%-54\%. Prognosis LLA pada anak di bawah usia 1 tahun dipengaruhi beberapa faktor, di antaranya usia pada saat diagnosis, angka leukosit awal yang tinggi, ekspresi CD10, ekspresi myeloid-associated antigen, translokasi 11q23/MLL (mixed-lineage leukemia) rearrangements, dan respon pada terapi awal.

Tujuan. Memberikan gambaran klinis dan luaran terapi pasien LLA anak usia di bawah satu tahun.

Metode. Laporan empat kasus LLA pada bayi mengenai perjalanan klinis, perawatan, dan hasil akhir pengobatan yang dirawat di Bagian Ilmu Kesehatan Anak RSUP Dr. Sardjito, Yogyakarta.

Hasil. Telah dirawat empat kasus LLA anak usia di bawah satu tahun. Satu kasus drop out dari pengobatan dan satu kasus meninggal pada fase awal pengobatan karena syok septik. Pasien tersebut datang dengan jumlah leukosit $2400 / \mu \mathrm{L}, \mathrm{CD} 10+(40 \%)$, dan imunofenotiping menunjukkan sel pre-B. Terapi yang diberikan adalah protokol risiko tinggi. Satu kasus yang sudah selesai pengobatan mempunyai jumlah leukosit awal 29.400/ $\mu \mathrm{L}, \mathrm{CD} 10+(68 \%)$, dan imunofenotiping menunjukkan sel pre-B. Satu pasien masih dalam pengobatan. Keempat pasien mengalami komplikasi berupa perdarahan dan sepsis.

Kesimpulan. Luaran terapi pasien LLA di bawah 1 tahun cukup baik, apabila dilakukan pendekatan terapi serta perawatan suportif yang optimal. Sangat perlu dilakukan pemeriksaan imunofenotiping, sitogenetik ataupun molekular untuk membantu stratifikasi risiko awal sehingga pengobatan dapat lebih tepat. (Sari Pediatri 2009;11(3):219-22).
\end{abstract}

Kata kunci: leukemia limfoblastik akut, usia, pengobatan

eukemia limfoblastik akut (LLA) pada anak usia di bawah satu tahun sangat jarang terjadi dan memiliki gambaran klinis yang buruk seperti hiperleukositosis, hepatosplenomegali,

\footnotetext{
Alamat korespondensi

Dr. Sri Mulatsih, Sp.A(K), Bagian Ilmu Kesehatan Anak, FK UGM RSUP Dr. Sardjito. Jl. Kesehatan No.1, Sekip Utara, Yogyakarta. Tel: (0274) 553142, Fax: (0274) 583745, E-mail: smulat@gmail.com
}

dan keterlibatan sistem saraf pusat. Translokasi gen MLL pada kromosom pita 11q23 yang muncul pada masa in utero adalah inti patogenesis LLA pada anak di bawah usia 1 tahun dan hal ini terdapat pada lebih dari 80\% kasus. Gen MLL pada kromosom pita 11q23 adalah gen yang berperan penting pada perkembangan dan defrensiasi sel hematopoetik. ${ }^{4,5}$ Rearrangements gen MLL menyebabkan terjadinya inhibisi apoptosis dan leukemogenesis. ${ }^{4}$ Translokasi pada gen MLL 
disebut juga leukemogenik dan melibatkan beberapa pasangan gen yang berbeda yang mengkode produksi protein dari beberapa tipe yang berbeda. Gen AF-4 pada kromosom pita 4q21 adalah pasangan gen MLL yang pada umumnya juga terdapat pada bayi dengan LLA. Gen ENL pada kromosom pita 19p13 adalah pasangan gen lainnya yang terdapat pada LLA. Keduanya mengkode faktor-faktor transkripsi. Translokasi gen MLL dipercaya menyebabkan leukemia dengan mekanisme fusi gen. ${ }^{4}$

Sel leukemia dengan 11q23 yang abnormal yang melibatkan rearrangement gen MLL bukan hiperdiploid, mempunyai pre-B sel imunofenotiping, dan mengekspresikan antigen mieloid tetapi bukan CD10. Insiden 11q23 yang abnormal pada bayi sekitar 60\%$80 \%$ pada seluruh LLA. Bayi dengan MLL/11q23 leukemia rearrangement memiliki EFS untuk 3 tahun sampai 6 tahun sebesar $5 \%$ sampai $28 \%$, sedangkan untuk bayi tanpa MLL/11q23 leukemia rearrangement memiliki EFS yang lebih baik untuk 3 tahun sampai 6 tahun yaitu 46\% sampai 91\%. MLL/11q23 rearrangement merupakan faktor prognosis yang buruk. ${ }^{1}$

Komplikasi pengobatan LLA pada bayi bisa akut dan jangka panjang. Hipogammaglobulinemia fisiologi pada bayi dapat berlarut-larut dan dengan mielosupresi, infeksi bakteri dan jamur dan infeksi jalur vena sentral sering terjadi. Sepsis, mikositis, perdarahan, toksisitas kardiak, dan pneumonitis interstisial menyebabkan kematian yang lebih sering terjadi pada bayi dibandingkan pada anak. ${ }^{4}$ Penelitian kami bertujuan untuk memberikan gambaran klinis dan luaran terapi pasien LLA anak usia di bawah satu tahun.

\section{Metode}

Dilaporkan empat kasus LLA pada bayi dan dicatat perjalanan klinis, perawatan, dan hasil akhir pengobatan.

\section{Hasil}

Secara ringkas faktor-faktor yang mempengaruhi prognosis keempat kasus di atas tertera pada Tabel 1.

\section{Pembahasan}

Keempat kasus yang dilaporkan terdiri dari satu perempuan dan tiga laki-laki. Dua di antaranya dengan usia kurang dari 6 bulan saat diagnosis. Berdasarkan referensi, usia kurang 6 bulan saat diagnosis memiliki prognosis yang lebih jelek dibandingkan dengan anak usia 6 bulan sampai 12 bulan. ${ }^{1}$ Kasus pertama dan ketiga datang dengan keluhan pucat, sedangkan dua kasus lainnya datang dengan keluhan perdarahan. Pada semua kasus didapatkan organomegali, tidak didapatkan tanda-tanda lekemia meningeal dan tidak ditemukan massa mediastinum. Pada kasus kedua ditemukan kejang, tetapi dari pemeriksaan cairan serebrospinalis

Tabel 1. Faktor yang mempengaruhi prognosis

\begin{tabular}{lllll}
\hline Faktor prognosis & Kasus 1 & Kasus 2 & Kasus 3 & Kasus 4 \\
\hline Usia & 10 bulan & $<6$ bulan & 9 bulan & $<6$ bulan \\
Jenis kelamin & Laki-laki & Laki-laki & Laki-laki & perempuan \\
Status gizi saat diagnosis & Gizi baik & Gizi baik & Gizi baik & Gizi baik \\
Leukosit awal & $4.550 / \mu \mathrm{L}$ & $29.400 / \mu \mathrm{L}$ & $2.400 / \mu \mathrm{L}$ & $99.500 / \mu \mathrm{L}$ \\
Limfoblas pada darah tepi awal & $15 \%$ & $88 \%$ & $88 \%$ & $81 \%$ \\
Limfoblas pada darah tepi minggu & $69 \%$ & $17 \%$ & $9 \%$ & $9 \%$ \\
pertama & & & & \\
Ekspresi CD 10 & Tidak ada data & $68 \%$ & $40 \%$ & $75 \%$ \\
Imunofenotiping & Tidak ada data & sel pre-B & sel pre-B & sel pre-B \\
Sitogenetik & Tidak ada data & Tidak ada data & Tidak ada data & Tidak ada data \\
Hepatosplenomegali & $(+)$ & $(+)$ & $(+)$ & $(+)$ \\
Lekemia meningeal & $(-)$ & $(-)$ & $(-)$ & $(-)$ \\
Status remisi pasca induksi & Belum remisi & Remisi & - & Remisi \\
Outcome & Drop out & Remisi pasca terapi & Meninggal (induksi & Masih dalam terapi \\
& & & minggu 4) & \\
\hline
\end{tabular}


dan CT-scan kepala tidak terbukti adanya meningeal lekemia. Dari CT-Scan didapatkan hasil higroma birontalis subdural. Pada kasus keempat didapatkan kejang pada saat perawatan, tetapi tidak jelas bukti ke arah leukemia meningeal. Pada kedua pasien tersebut tidak ditemukan defisit neurologis. Hal ini tidak sesuai dengan teori yang menyatakan bahwa gambaran LLA pada bayi biasanya melibatkan sistem saraf pusat. ${ }^{1}$

Imunofenotiping yang sering pada bayi dengan LLA adalah CD19+, CD10-, CD15+, dan atau CD65+, NG2+. ${ }^{5}$ Kadar CD10 negatif mempunyai hubungan yang kuat tetapi tidak seluruhnya dengan rearrangement MLL/11q23. Bayi tanpa ekspresi CD10 dilaporkan memiliki EFS 21\% sampai 40\% untuk 4 sampai 6 tahun, dan dengan ekspresi CD10 mempunyai EFS $45 \%$ sampai $75 \%$ untuk 4 sampai 6 tahun pada bayi dengan $\mathrm{CD} 10^{+}$pada sel blastnya. ${ }^{1}$ LLA pada bayi biasanya mempunyai karakteristik imunofenotiping sel B prekursor dengan ekspresi antigen CD19+, $\mathrm{TdT}+$, HLA DR+, CD10- (CALLA). Kurangnya ekspresi CD10 adalah faktor prognosis yang buruk. , $^{4,7}$

Jika dilihat dari hasil laboratorium awal, hanya satu kasus dengan jumlah leukosit lebih dari 50.000/ $\mu \mathrm{L}$ dan mendapatkan terapi untuk sindrom lisis tumor, dan sekarang masih menjalani kemoterapi. Pada pemeriksaan aspirasi sumsum tulang keempat kasus ditemukan limfoblas dengan klasifikasi FAB adalah ALL-L1 dan immunofenotiping kasus adalah sel pre-B dengan ekspresi CD10 positif. Hal ini sesuai dengan referensi bahwa ekspresi CD10 yang positif berarti memiliki faktor prognosis yang baik. ${ }^{4,7}$

Diperlukan pendekatan khusus untuk pengobatan karena respons yang tidak baik. Regimen CCG170 untuk bayi tanpa radiasi kranial menambahkan daunorubisin pada induksi dan metrotreksate dosis tinggi $\left(33 \mathrm{~g} / \mathrm{m}^{2}\right)$ untuk sistemik dan ekstramedular pada konsolidasi dan intensifikasi, menghasilkan remisi induksi $88 \%$ dan peningkatan 4 tahun EFS menjadi $33 \%$. Protokol pengganti yaitu CCG 1883 bermaksud untuk lebih memaksimalkan toleransi pada kemoterapi pasca induksi dengan menambahkan sitosin arabinase, L-asparaginase, dan siklofosfamid sistemik, dan metotreksate intratekal untuk konsolidasi. Remisi induksinya mencapai 94\% dan 4 tahun EFS nya 39\% ${ }^{4}$. Pada penelitian ALL-BFM 83, kelompok BerlinFrankfurt-Mùnster (BFM) telah mendemonstrasikan faktor prognosis yang signifikan dari reduksi sel blast di pembuluh darah perifer dengan 7 hari prefase prednison dan satu dosis metotreksat intratekal sebagai parameter awal respon terapi. Respon prednison ini memiliki nilai faktor prognosis yang sangat tinggi terhadap parameter outcome atau luaran. Dari penelitian mereka didapatkan EFS untuk 6 tahun 53\% pada kelompok prednison good response, dan probabilitas EFS $15 \%$ untuk kelompok prednison poor response. ${ }^{7}$

Satu kasus selesai menjalani pengobatan dan remisi, satu kasus meninggal pada fase induksi minggu ke-4 karena septisemia, satu kasus hilang dari pengamatan, dan satu kasus masih menjalani kemoterapi yang sudah memasuki fase konsolidasi. Satu pasien menggunakan kemoterapi menurut protokol WK-ALL 2000, sedangkan tiga lainnya menjalani protokol Indonesia ALL-HR 2006. Protokol Indonesia ALL-HR 2006 mendapat tambahan daunorubisin dan L-asparaginase pada fase induksi, metotreksat dosis tinggi dan siklofosfamid pada fase konsolidasi, serta tambahan sitarabin pada fase reinduksi.

Satu kasus yang sudah selesai menjalani pengobatan dan dinyatakan remisi, walaupun usia pada saat diagnosis di bawah 6 bulan, tetapi memiliki faktor prognosis lain yang baik. Angka leukosit awal yang tidak tinggi, tidak ditemukannya leukemia meningeal, respon yang baik pada minggu pertama terapi, dan ekspresi CD10 yang positif merupakan faktor prognosis yang baik.

Satu kasus meninggal pada fase induksi walaupun usia di atas 6 bulan tetapi memiliki faktor prognosis yang buruk. Berdasarkan evaluasi darah tepi respon awal terapi minggu pertama menunjukkan respon yang baik. Limfoblast turun dari $88 \%$ menjadi $9 \%$, tetapi hal ini diikuti dengan turunnya sel granulosit sehingga menyebabkan pasien rentan terhadap infeksi dan tidak didukung dengan perawatan suportif yang baik sehingga menyebabkan pasien mengalami sepsis yang sulit diatasi dan akhirnya pasien meninggal. Pada pasien tersebut ekspresi CD10 ditemukan positif, tetapi kadarnya lebih rendah dibandingkan dua kasus lainnya.

Komplikasi yang ditemukan pada keempat kasus tersebut adalah perdarahan, sepsis, infeksi bakterial, infeksi jamur, dan dekubitus, yang mendapat pengobatan sesuai dengan komplikasi yang ada. Kasus ketiga mengalami komplikasi perdarahan hebat dan disertai dengan infeksi berat dan akhirnya meninggal karena septikemia.

Pada keempat kasus tidak dilakukan pemeriksaan sitogenetik karena keterbatasan fasilitas. Sitogenetik merupakan faktor prognosis yang mempengaruhi outcome. ${ }^{2}$ 
Disimpulkan bahwa gambaran klinis pasien LLA di bawah satu tahun sangat bervariasi. Jumlah leukosit awal, dan ekspresi CD +10 merupakan faktor prognosis terhadap keberhasilan pengobatan. Diperlukan perawatan suportif yang optimal karena pasien mendapatkan pengobatan dengan protokol risiko tinggi, sehingga akan mengalami efek samping yang berat termasuk supresi sel tubuh dan risiko mendapat infeksi.

\section{Daftar Pustaka}

1. Hilden JM, Dinndrorf PA, Meerbaum SO, Sather H, Villaluna D, Heerema NA, dkk. Analysis of prognostic factor of acute lymphoblastic leukemia in infants: report on CCG 1953 from the Childrens's Oncology Group. Blood 2006;108:441-51.

2. Reaman GH, Sposto R, Sensel MG, Lange BJ, Feus- ner JH, Heerema NA, dkk. Treatment outcome and prognostic factor for infants with acute lymphoblastic leukemia treated on two consecutive of the Children's Cancer Group. J Clin Oncol 1999;17:445-55.

3. Pui CH, Evans WE. Acute lymphoblastic leukemia in infants. J Clin Oncol 1999;17:438-40.

4. Felix CA, Lange BJ, Chessells JM. Pediatric acute lymphoblastic leukemia: challenges and controversies in 2000. Hematology 2000; 285-302.

5. Gurgey A, Yetgin S, CetinM, Gumruk F, Tuncer AM, Turclibek E, dkk. Acute lymphoblastic leukemia in infants. Turkish J Pediatr 2004; 46:115-9.

6. Raimondi SC. $11 \mathrm{q} 23$ rearrangements in childhood acute lymphoblastic leukemia. Atlas Genet Cytogenet Oncol Haematol 2004;16:31-7.

7. Dordelmann M, Reiter A, Borkhardt A, Ludwig WD, Gotz N, Viehmann S, dkk. Prednisone response is the strongest predictor of treatment outcome in infant acute lymphoblastic leukemia. Blood 1999; 94:1209-17. 